\title{
Pola Pertumbuhan Bakteri Ureolitik pada Medium Calcium Carbonat Precipitation (CCP)
}

\author{
Rindan Novanti dan Enny Zulaika \\ Departemen Biologi, Fakultas Ilmu Alam, Institut Teknologi Sepuluh Nopember (ITS) \\ e-mail: enny@bio.its.ac.id
}

\begin{abstract}
Abstrak-Bakteri ureolitik merupakan bakteri yang dapat menghasilkan urease untuk menghidrolisis urea. Bakteri ureolitik menggunakan urea sebagai sumber energi. Tujuan dari penelitian ini adalah mengetahui pola pertumbuhan bakteri ureolitik pada medium CCP. Subkultur isolat bakteri ureolitik dilakukan pada medium CCP agar miring, pengamatan pola pertumbuhan isolat bakteri ureolitik dilakukan pada medium CCP cair selama 18 jam. Semua isolat menunjukkan fase adaptasi pada 0-2 jam, fase eksponensial terjadi pada 4-10 jam, fase stasioner terjadi mulai dari 14 jam dan fase kematian terjadi pada 14-18 jam. Pola pertumbuhan isolat JA1, JB2 dan JA4 menunjukkan pola yang hampir sama, isolat SU1 pola pertumbuhannya hampir sama dengan $\mathrm{AK} 4$, dan isolat JB3 menunjukkan pola pertumbuhan yang berbeda dengan isolat lainnya.
\end{abstract}

Kata Kunci-Bakteri Ureolitik, CCP, Pola Pertumbuhan.

\section{PENDAHULUAN}

B AKTERI ureolitik merupakan bakteri yang menghasilkan urease untuk menghidrolisis urea. Urease mengkatalisis hidrolisis urea menjadi ammonia dan karbonat, yang mengakibatkan peningkatan $\mathrm{pH}$ dan pembentukan kristal kalsium karbonat di lingkungan [1]. Bakteri ureolitik dapat ditemukan di pegunungan kapur, guagua karst ataupun di sedimen [2].

Bakteri ureolitik telah ditemukan di gua batu kapur Sarawak, Malaysia Timur. Bakteri ureolitik dari isolasi dan uji kualitatif enzim urease tersebut yaitu Sporosarcina pasteurii, Bacillus lentus dan Sporosarcina luteola [3]. Bakteri ureolitik pada tanah berkapur di India ditemukan 5 bakteri yang dapat menghasilkan enzim urease yaitu Bacillus megaterium, Bacillus thuringiensis, Bacillus cereus, Bacillus subtilis dan Lactobacillus fusiformis [4].

Urease merupakan enzim yang mengkatalis hidrolisis dari urea menjadi ammonia dan karbonat. Pada umumnya urease dapat ditemukan pada bakteri, yeast, fungi, alga, invertebrata dan tumbuhan [5]. Enzim ini menggunakan urea sebagai substrat yang akan dihidrolisis menjadi amonia dan asam karbonat sebagai produk akhir. Urease berperan dalam memudahkan organisme menggunakan urea sebagai sumber nitrogen dan energi [6].

Pola pertumbuhan mikroorganisme terdiri dari 4 fase yaitu fase adaptasi, fase eksponensial, fase stasioner dan fase kematian [7]. Fase adaptasi menunjukkan pertumbuhan awal kultur bakteri setelah diinokulasikan pada medium baru. Pertumbuhan biasanya tidak langsung terjadi, akan tetapi dibutuhkan jangka waktu untuk bakteri beradaptasi. Suatu bakteri yang ditumbuhkan pada medium yang menyerupai lingkungan aslinya tidak akan memiliki fase lag dan fase logaritmas akan terjadi. Fase logaritma menunjukkan pembelahan biner sel bakteri secara aktif [7].

Fase stasioner merupakan keadaan saat fase logaritma berhenti dan tidak adanya laju pertumbuhan. Kondisi ini dapat disebabkan oleh dua faktor penghambat pertumbuhan yaitu nutrien habis terpakai dan produk samping hasil metabolisme menumpuk dalam medium hingga menghambat pertumbuhan. Fase kematian terjadi saat penurunan jumlah nutrisi dan peningkatan jumlah produk samping mengakibatkan viabilitas sel yang semakin menurun. Sel mikroba yang mati akan mengalami lisis. Fase kematian juga terjadi dengan adanya perubahan lingkungan menjadi tidak menguntungkan, seperti meningkatnya akumulasi zat toksik dalam medium pertumbuhan [7]. Penelitian ini bertujuan untuk mengetahui pola pertumbuhan bakteri ureolitik pada medium Calcium Carbonat Precipitation (CCP).

\section{METODOLOG}

\section{A. Waktu dan Tempat Penelitian}

Penelitian ini dilaksanakan di Laboratorium Mikrobiologi dan Bioteknologi Departemen Biologi, Fakultas Ilmu Alam, Institut Teknologi Sepuluh Nopember Surabaya. Waktu penelitian bulan Februari 2018 sampai dengan Juni 2018.

\section{B. Isolat yang Digunakan}

Isolat yang digunakan adalah isolat yang diisolasi dari daerah berkapur Bangkalan, Gresik dan Tuban, yaitu JA1, JA4, JB2, JB3, AK4, SU1.

\section{Subkultur Isolat Bakteri Ureolitik}

Isolat murni bakteri ureolitik dari stok murni ditumbuhkan pada medium Calcium Carbonat Precipitation (CCP) agar miring dalam tabung reaksi. Komposisi medium CCP (per liter) 20 gr urea; 2,12 gr $\mathrm{NaHCO}_{3} ; 10$ gr $\mathrm{NH}_{4} \mathrm{Cl} ; 3 \mathrm{gr}$ Natrium Broth; $30 \mathrm{mM} \mathrm{CaCl} 2 ; 20$ gr agar; $\mathrm{NaOH} 2 \mathrm{M}$ [2]. Selanjutnya di autoclave selama 15 menit pada suhu $121^{\circ} \mathrm{C}$. Medium di tuang dalam tabung reaksi dan dibentuk agar miring. Inokulasi isolat dilakukan menggunakan jarum ose secara aseptis, sebanyak 1 ose dari masing-masing isolat diinokulasikan pada medium CCP agar miring, kemudian diinkubasi dalam suhu ruang $\left(30^{\circ} \mathrm{C}\right)$ selama 24 jam. Keberhasilan subkultur ditandai dengan tumbuhnya koloni bakteri.

\section{Pola Pertumbuhan}

Pola pertumbuhan dilakukan untuk menentukan umur isolat bakteri ureolitik. Pertumbuhan isolat bakteri ureolitik diamati pada medium CCP cair selama 18 jam. Isolat 
diambil sebanyak 3 ose kemudian dimasukkan ke dalam 100 $\mathrm{ml}$ medium CCP cair selanjutnya diinkubasi selama 18 jam pada suhu ruang di atas rotary shaker dengan kecepatan 100 rpm.Pengamatan Optical Density (OD) dengan menggunakan spektrofotometer UV-Vis pada panjang gelombang $600 \mathrm{~nm}$ [8]. Pengukuran Optical Density (OD) dimulai dari jam ke-0 hingga jam ke-3 dengan interval 30 menit, selanjutnya interval setiap 2 jam sekali hingga jam ke-18. Data Optical Density (OD) yang didapatkan kemudian dibuat kurva pertumbuhan dengan sumbu $\mathrm{x}$ sebagai waktu (t) dan sumbu y sebagai hasil Optical Density (OD).

\section{HASIL DAN PEMBAHASAN}

Pola pertumbuhan isolat bakteri ureolitik terdiri dari 4 fase yaitu fase adaptasi, fase eksponensial, fase stasioner dan fase kematian [9]. Pertumbuhan dari isolat JA1, JB2 dan JA4 menunjukkan pola yang hampir sama, untuk isolat SU1 pola pertumbuhannya hampir sama dengan AK4, sedangkan isolat JB3 menunjukkan pola berbeda dengan isolat lainnya (Gambar 1).

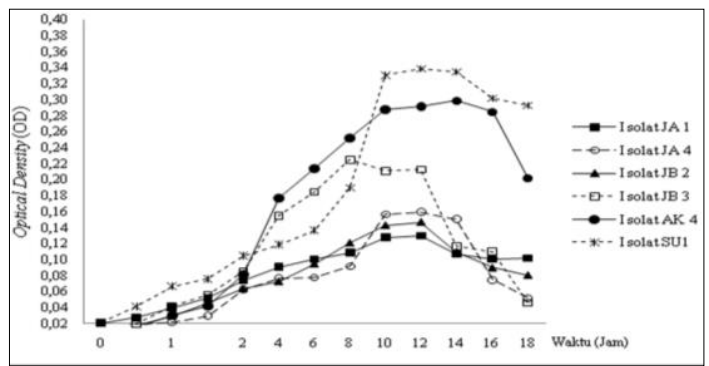

Gambar 1. Pola Pertumbuhan Isolat Bakteri Ureolitik pada medium Calcium Carbonat Precipitation (CCP).

Semua isolat menunjukkan fase adaptasi atau merupakan awal pertumbuhan kultur bakteri pada 0-2 jam. Fase adaptasi menunjukkan pertumbuhan awal kultur bakteri setelah diinokulasikan pada medium baru. Pertumbuhan biasanya tidak langsung terjadi karena dibutuhkan jangka waktu untuk bakteri beradaptasi [9]. Fase eksponensial pada semua isolat terjadi pada 4-10 jam. Fase eksponensial merupakan fase pembelahan sel yang berlangsung secara cepat karena adanya peningkatan aktivitas metabolisme, sehingga pada fase ini sel berkembang secara optimum [10]. Fase stasioner terjadi pada jam yang tidak sama antara isolat satu dengan yang lainnya. Lamanya fase stasioner antara 2-3 jam. Pada fase stasioner metabolisme bakteri mulai melambat karena penurunan jumlah nutrisi yang dibutuhkan dalam pertumbuhannya [11]. Kebutuhan nitrogen dan energi bakteri ureolitik untuk pertumbuhan dapat tercukupi melalui hidrolisis urea [12]. Urease digunakan bakteri ureolitik untuk menghidrolisis urea menjadi ammonia dan karbonat. Urea menyediakan energi dan sumber nitrogen untuk bakteri. Urea juga berperan sebagai sumber ion karbonat $\left(\mathrm{CO}_{3}{ }^{2-}\right)$ dalam presipitasi kalsium karbonat $\mathrm{CaCO}_{3}$ [13] ATP yang dihasilkan berhubungan dengan produksi ion ammonium $\left(\mathrm{NH}_{4}{ }^{+}\right)$dari hidrolisis urea [14].

Urea dalam medium yang semakin lama mulai habis dapat meyebabkan pertumbuhan sel bakteri yang menurun dan akan memasuki fase kematian. Fase kematian pada semua isolat dimulai setelah jam ke 14 dari inokulasi, kecuali isolat JB2 pada jam ke 16 dan isolat AK4 pada jam ke 18. Nutrisi dalam medium sebagai substrat yang mengalami penurunan dapat mengakibatkan pertumbuhan sel yang semakin menurun [15]. Fase kematian terjadi saat nutrisi telah habis sehingga mengakibatkan pertambahan sel yang semakin menurun karena jumlah sel bakteri yang mati lebih banyak dibandingkan terbentuknya sel baru [9].

\section{KESIMPULAN/RINGKASAN}

Pola pertumbuhan bakteri ureolitik pada medium Calcium Carbonat Precipitation (CCP) menunjukkan bahwa pola pertumbuhan yang hampir sama pada isolat JA1, JB2 dan JA4. Isolat SU1 pola pertumbuhannya hampir sama dengan AK4, dan isolat JB3 menunjukkan pola berbeda dengan isolat lainnya dalam pertumbuhannya.

\section{DAFTAR PUSTAKA}

[1] P. A. G. Krishnapriya, S. D. L., Venkatesh B., "Isolation and Identification of Bacteria to Improve the Strength of Concrete," J. Microbiol. Res., vol. 174, pp. 48-55, 2015.

[2] and N. Wei S., Hongpeng, C., Zhonglong, F., Hao, L., Hao, H., "F. Biomineralization Processes of Calcite Induced by Bacteria Isolated From Marine Sediments," Brazilians J. Microbiol., vol. 2, pp. 455-464, 2015.

[3] M. N. Omoregie, A. I., Nurnajwani, S., Phua, Y. L., Ngu, L. H., Dominic, O. E. L., Irene, R. H. G. And Peter, "Ureolytic Bacteria Isolated from Sarawak Limestone Caves Show High Urease Enzyme Activity Comparable to that of Sporosarcina pasteurii (DSM 33)," Malays. J. Microbiol., vol. 12, no. 6, pp. 463-470, 2016.

[4] and M. Dhami, N. K., Reddy, M. S., "A. Biomineralization of Calcium Carbonates and Their Enginered Applications: A Review," Front Microbiol, vol. 4, p. 314, 2013.

[5] B. Sujoy and A. Aparna, "Enzymology, Immobilization and Application of Urease Enzyme," Int. Res. J. Biol. Sci, vol. 2, pp. 51-56, 2013.

[6] B. Krajewska, "Ureases 1. Functional Catalyv and Kinetic Properties: A Review," J.Mol. Catal. B Enzym, vol. 59, no. 1-3, pp. 9-21, 2009.

[7] J. M. M. and J. P. Madigan, M.T., Brock Biology of Microorganisms. Prentice hall International Inc, 2002.

[8] H. dan Prescott, Laboratory Exercises in Microbioogy, Fifth Edition. The Mcgraw-Hill Companies, 2002.

[9] D. P. Madigan, M. T., Martinko, J. M., Stahl, D., dan Clark, Brock Biology of Microorganisms (13th Edition). New York: Pearson, 2012.

[10] C. D. . Rolfe, M.D., Christopher, J.R., Sacha, L., Carmen, P., Arthur, T., Andrew, D.S., Cameron, M.A., Michael, F. S., Roy, P.B., Jozsef, B., Michael, W.P., dan Jay, "Lag Phase Is a Distinct Growth Phase That Prepares Bacteria for Exponential Growth and Involves Transient Metal Accumulation," Int. J. Bacteriol., vol. 194 , no. 3, pp. 686-701, 2012.

[11] M. Assaduzzaman, "Standardization of Bacterial Growth Curves from Several Curves with Different Initial Sizes," Res. Pap. Div. Sci. Chalmers, 2007.

[12] A. Dhami, Kaur, N., Reddy, M.S., Mukherjee, "Biomineralization of Calcium Carbonate Polymorphs by the Bacterial Strains Isolated from Calcareous Sites," J. Microbiol. Biotechnol., vol. 23, no. 5, pp. 707-714, 2015.

[13] J. De Belie, N. and Wang, "Bacteria-based repair and selfhealing concrete," J. Sustain. Cem. Mater., vol. 5, p. 35, 2015.

[14] S. . Al-Thawadi, "Ureolytic Bacteria and Calcium Carbonate Formation as a Mechanism of Strength Enhancement of Sand," $J$. Adv. Sci. Eng. Res., vol. 1, pp. 98-114, 2011.

[15] E. . Oyeleke, S.B., Auta, S.H., dan Egwim, "Production and characterization of amylase produce by Bacillus megatirium isolated from a local yam peel dumpsite in Minna, Niger State," J. Microbiol. Antimicrob., vol. 2, pp. 88-92, 2010. 